19 Revue d'histoire du XIXe siècle

Société d'histoire de la révolution de 1848 et des

révolutions du XIXe siècle

$11 \mid 1995$

L'exil

\title{
Exilés et voyageurs en Hongrie
}

\section{Claude Schkolnyk}

\section{OpenEdition}

Journals

\section{Electronic version}

URL: http://journals.openedition.org/rh19/82

DOI: $10.4000 /$ rh19.82

ISSN: $1777-5329$

\section{Publisher}

La Société de 1848

\section{Printed version}

Date of publication: 1 June 1995

ISSN: 1265-1354

\section{Electronic reference}

Claude Schkolnyk, «Exilés et voyageurs en Hongrie », Revue d'histoire du XIXe siècle [Online], 11 | 1995 Online since 09 September 2008, connection on 22 April 2019. URL : http://journals.openedition.org/ rh19/82 ; DOI : 10.4000/rh19.82

This text was automatically generated on 22 April 2019

Tous droits réservés 


\section{Exilés et voyageurs en Hongrie}

\section{Claude Schkolnyk}

\section{ABSTRACTS}

Exiles and travellers in Hungary Through the lives of the Guerrier-Tynaire family and the writer Louis-Auguste Rogeard, Claude Schkolnyk sketches the portrait of a little-known community, that of the Paris Commune members who were exiled in Hungary. These men and women had already suffered imperial repression, which had seen them imprisoned and exiled closer to France in England, Switzerland or Belgium. Through the Commune, they met international activists such as the Hungarian Léo Franckel, and this time, exile led them further afield. The enthusiasm with which they were received may seem surprising. But then, they appeared less as "red flag bearers" than as the representatives of the cradle of democracy and as staunch supporters of the emancipation of women. The Gérando-Teleki family seems to have continued to be a key link in the communication networks between France and Hungary. The next generation of this family inherited the same taste for adventure and travelling.

À travers les itinéraires de la famille Guerrier-Tynaire et du publiciste Louis-Auguste, Claude Schkolnyk trace le portrait d'une communauté peu connue, celle des communards qui vécurent l'exil en Hongrie. Ces hommes et ces femmes ont déjà connu la répression impériale qui les a conduit en détention et déjà à l'exil, exil plus proche en Angleterre, Suisse et Belgique. Avec la Commune et la rencontre de militants internationaux comme le hongrois Léo Franckel, la proscription les conduit plus loin. L'accueil qui leur est fait peut surprendre par son enthousiasme. Mais ils apparaissent moins ici comme des "porteurs de drapeau rouge " que comme des représentants du berceau de la démocratie et comme d'ardents défenseurs de l'émancipation des femmes. La famille Gérando-Teleki apparaît comme un maillon toujours essentiel des réseaux d'échanges entre Français et Hongrois. La génération suivante garde de cette aventure familiale le gôut de l'aventure et des voyages. 
INDEX

Mots-clés: Exil, Voyage, Hongrie 